\title{
Use of Smartphone Funduscopy to aid Diagnosis of chorioretinitis after donor-recipient mismatched cardiac transplantation
}

\author{
Lanxing Fu
}

Manchester Royal Eye Hospital, Manchester, UK

\section{Correspondence to \\ Dr Lanxing Fu,}

LFU@Doctors.org.uk

Accepted 15 September 2017

\section{DESCRIPTION}

A 52-year-old man was referred for an ophthalmological opinion after becoming generally unwell and developing reduced vision in the left eye. He had had a cardiac transplant 6 months prior and was being followed up on an outpatient basis. Unfortunately, he was too unwell to be transferred to the ophthalmology department; bedside examination in intensive care found vision to be $6 / 60$ with two retinal lesions and vitritis in the left eye.

Infection screening found PCR positivity for toxoplasmosis and cytomegalovirus (CMV). A myocardial biopsy revealed intramyocardial cysts consistent with toxoplasmosis infection. The recipient was seronegative for toxoplasmosis, but the donor was positive. Both the donor and recipient were seropositive for CMV. The patient had received pretransplant prophylaxis treatment but this was stopped before the course finished due to intolerance. Clinically, the findings were not fully consistent with either ocular toxoplasmosis or CMV infection.

With the patient's consent, funduscopic documentation was undertaken with an iPhone 6 (Apple, Cupertino, California, USA) and a 28D lens (Volk Optical, Mentor, Ohio, USA). No additional hardware attachments or third-party external

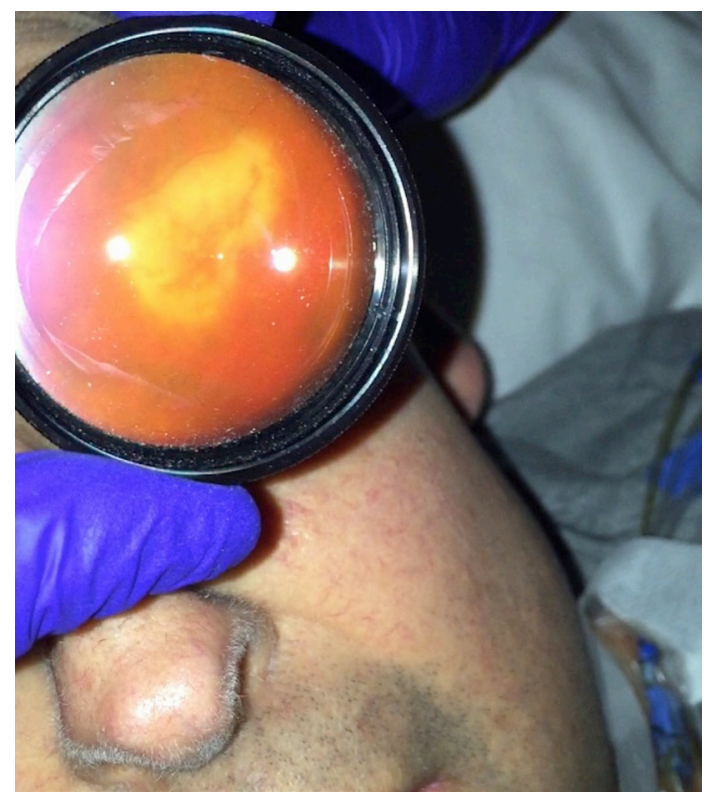

To cite: Fu L. BMJ Case Rep Published Online First: [please include Day Month Year]. doi:10.1136/bcr-2017221981
CrossMark

Figure 1 iPhone indirect image of the left fundus taken with a $28 \mathrm{D}$ lens demonstrating a retinal lesion and vitritis (hazy view).

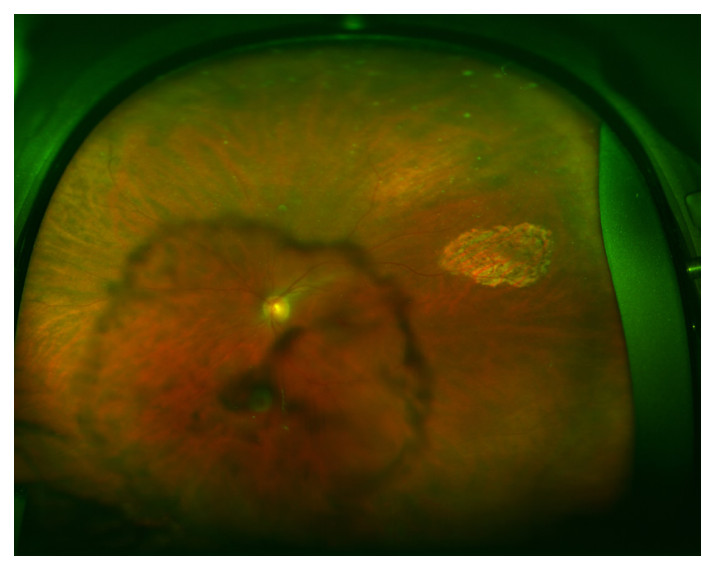

Figure 2 Optos widefield view of the whole fundus on resolution and visual recovery.

applications were used (figure 1). This allowed for senior input and the patient was commenced on combination therapy (intravenous ganciclovir $2.5 \mathrm{mg} / \mathrm{kg}$, oral pyrimethamine and clindamycin). The patient improved clinically and vision recovered to 6/6 in the left eye (figure 2).

Management of infection in solid-organ transplant recipients is challenging because clinical progression can be rapid, diagnosis can be delayed, with a wide spectrum of potential pathogens. Transplant recipients often have reduced immune function; hence, signs and symptoms of disease can be diminished or atypical. ${ }^{1}$ Invasive diagnostic procedures such as vitreous sampling pose an additional infection risk and fortunately was not necessary in this patient.

Fundus photography has been an established and essential part of ophthalmic practice, allowing for documentation of ocular disease, aiding diagnosis and sharing of information between clinicians. Traditionally, fundus cameras are expensive, have compatibility issues and are not portable. Smartphones are now available worldwide, providing a potential new platform for image documentation. In a situation where outlier patients are needing regular clinical review, it is not always possible to have the same person review the patient. Hence, there is the need for objective documentation of clinical findings. Smartphone funduscopy uses a condensing lens, a smartphone camera, in-built video capture software and adjacent flashlight. The flashlight acts as a coaxial light source turning the smartphone into an indirect ophthalmoscope. ${ }^{2}$ Images captured by video recording can be 
extracted either alone or with additional third-party external applications. The major limitation remains image quality and the limited field of view. Further validation studies are still necessary to assess how smartphone funduscopy can be used in routine clinical practice. ${ }^{3}$

Smartphone funduscopy can be a useful aid in clinical assessment, especially for inaccessible patients. The simplicity, relative

\section{Learning points}

Infection in transplant patients can present with diminished or atypical signs because of their reduced immune function.

- Timely diagnosis and initiation of treatment can improve visual prognosis.

- Smartphone funduscopy can be a useful aid in the initial assessment, documentation and diagnosis in clinical situations where timing, convenience and portability are necessary. inexpensiveness and platform compatibility of smartphones are ideal properties for use in non-traditional settings and in geographically remote areas of the world.

Contributors LF designed the work, collected the images, drafted and critically reviewed the final manuscript.

Competing interests None declared.

Patient consent Obtained.

Provenance and peer review Not commissioned; externally peer reviewed.

(C) BMJ Publishing Group Ltd (unless otherwise stated in the text of the article) 2017. All rights reserved. No commercial use is permitted unless otherwise expressly granted.

\section{REFERENCES}

1 Fishman JA. Infection in solid-organ transplant recipients. N Engl J Med 2007;357:2601-14

2 Haddock LJ, Kim DY, Mukai S. Simple, inexpensive technique for high-quality smartphone fundus photography in human and animal eyes. J Ophthalmol 2013;1-5.

3 Russo A, Morescalchi F, Costagliola C, et al. Comparison of smartphone ophthalmoscopy with slit-lamp biomicroscopy for grading diabetic retinopathy. Am J Ophthalmol 2015;159:360-4.

Copyright 2017 BMJ Publishing Group. All rights reserved. For permission to reuse any of this content visit http://group.bmj.com/group/rights-licensing/permissions.

BMJ Case Report Fellows may re-use this article for personal use and teaching without any further permission.

Become a Fellow of BMJ Case Reports today and you can:

- Submit as many cases as you like

- Enjoy fast sympathetic peer review and rapid publication of accepted articles

- Access all the published articles

Re-use any of the published material for personal use and teaching without further permission

For information on Institutional Fellowships contact consortiasales@bmjgroup.com

Visit casereports.bmj.com for more articles like this and to become a Fellow 